\title{
Cyanobacteria-derived nitrogen uptake by benthic invertebrates in Lake Taihu: a mesocosm study using ${ }^{15} \mathrm{~N}$ labeling
}

\author{
J. Yu(1),(2),, H. He ${ }^{(1)}$, Z. Liu(1),(2),(3), K. Li(1), Y. Hu(1), P. Zhong ${ }^{(2)}$, E. Jeppesen ${ }^{(3),(4)}$
}

Received September 22, 2014

Revised October 19, 2014

Accepted October 23, 2014

Key-words:

Microcystis

detritus,

Benthic

invertebrates,

nitrogen,

labeling

experiment,

food web

\section{ABSTRACT}

Eutrophication of lakes can lead to dominance by cyanobacteria, which are hardly used by zooplankton due to their low nutrition value. However, sedimented cyanobacterial detritus may be a useful source for benthic invertebrates. We studied the Microcystis-derived nitrogen incorporation in benthic invertebrates in Lake Taihu using stable isotopic nitrogen $\left({ }^{15} \mathrm{~N}\right)$ as a tracer. The $\delta^{15} \mathrm{~N}$ of all organisms increased significantly with time after addition of the labeled Microcystis detritus. $\delta^{15} \mathrm{~N}$ values of POM and periphyton peaked earlier than for benthic invertebrates, and the maximum levels were also higher than bivalves, snails and worms (Limnodrilus spp.). Among benthic invertebrates, Radix swinhoei peaked later than other invertebrates, but the maximum level and the excess ${ }^{15} \mathrm{~N}$ of the last sampling day were higher. At the end of the experiment, approximately $70 \%$ of the added ${ }^{15} \mathrm{~N}$ was retained in the benthic food web, while only a small fraction (less than 1\%) of the added detritus ${ }^{15} \mathrm{~N}$ occurred in the pelagic food web. Our results suggest that nitrogen from cyanobacteria can be incorporated more in benthic than pelagic food webs and cyanobacterial blooms may contribute to the development of benthic animals.

\section{RÉSUMÉ}

L'absorption d'azote provenant de cyanobactéries par les invertébrés benthiques dans le lac Taihu : une étude en mésocosme utilisant un marquage ${ }^{15} \mathrm{~N}$

Mots-clés : détritus de Microcystis, invertébrés benthiques, azote, expérience de marquage, réseau trophique
L'eutrophisation des lacs peut conduire à la dominance des cyanobactéries, qui sont très peu utilisées par le zooplancton en raison de leur faible valeur nutritionnelle. Cependant, les détritus sédimentés de cyanobactéries peuvent être des sources utiles pour les invertébrés benthiques. Nous avons étudié l'incorporation d'azote provenant de Microcystis par les invertébrés benthiques dans le lac Taihu en utilisant de l'azote isotopique stable $\left({ }^{15} \mathrm{~N}\right)$ comme traceur. Le $\delta^{15} \mathrm{~N}$ de tous les organismes a augmenté de manière significative au cours du temps après l'addition du détritus de Microcystis marqué. Les valeurs de $\delta^{15} \mathrm{~N}$ de POM et du périphyton ont atteint un maximum plus tôt que pour les invertébrés benthiques, et les teneurs maximales étaient également plus élevées que chez les bivalves,

(1) State Key Laboratory of Lake Science and Environment, Nanjing Institute of Geography and Limnology, Chinese Academy of Sciences, Nanjing 210008, P.R. China

(2) Department of Ecology and Institute of Hydrobiology, Jinan University, Guangzhou 510630, P.R. China

(3) Sino-Danish Center for Education and Research (SDC), Beijing, P.R. China

(4) Department of Bioscience, Aarhus University, 8600 Silkeborg, Denmark

^ Corresponding author: jlyu@niglas.ac.cn 
les escargots et les vers (Limnodrilus spp.). Chez les invertébrés benthiques, Radix swinhoei a atteint un sommet plus tard que pour d'autres invertébrés, mais le niveau maximum et l'excès en ${ }^{15} \mathrm{~N}$ de la dernière journée d'échantillonnage étaient plus élevés. À la fin de l'expérience, environ $70 \% d u{ }^{15} \mathrm{~N}$ ajouté a été retenu dans la chaîne alimentaire benthique, tandis que seule une petite fraction (moins de 1 \%) $d u{ }^{15} \mathrm{~N}$ ajouté est retenue dans le pélagique. Nos résultats suggèrent que l'azote de cyanobactéries peut être incorporé dans les réseaux trophiques benthiques plus que dans les pélagiques et la prolifération de cyanobactéries peut contribuer au développement des animaux benthiques.

Due to anthropogenic eutrophication, which generally leads to an increasing contribution of cyanobacteria to the total algal biomass (Watson et al., 1997), cyanobacterial blooms have been one of the most common problems in freshwater waterbodies (Paerl, 1988).

Cyanobacteria have commonly been regarded as a diet item low in nutritional value for aquatic animals because of their morphology and toxin content (Lampert, 1987). However, cyanobacteria-derived detritus may be a potential nutritional source for aquatic consumers (Yu et al., 2013) that are usually abundant in density. Thus, the bloom-forming cyanobacteria in shallow lakes may provide numerous food resources for the aquatic animals and potentially support the nutrient flows of local food webs. To confirm this, we conducted mesocosm experiments to simulate the ecosystem of Meiliang Bay, one of the most eutrophic parts of Lake Taihu, to investigate the fate of nitrogen derived from Microcystis detritus in the food web using ${ }^{15} \mathrm{~N}$ as a tracer. The quantity of cyanobacterial detritus retained by benthic primary consumers and the proportion of nitrogen derived from cyanobacteria retained in the pelagic and benthic food webs were compared.

The experiment was conducted at the shore of Meiliang Bay, the northern part of Lake Taihu, China. The bay is currently hypereutrophic, which is characterized by almost complete dominance by Microcystis spp. of the phytoplankton biomass in summer (Chen et al., 2003a), with recurrent cyanobacterial blooms dominated by Microcystis spp. (Duan et al., 2009). Samples of Microcystis aeruginosa (>99\%) during cyanobacterial blooms were collected from Meiliang Bay in August, 2010. The live Microcystis was labeled with ${ }^{15} \mathrm{NH}_{4} \mathrm{Cl}$ and, after incubation, Microcystis cells were collected with a $30-\mu \mathrm{m}$ net and washed repeatedly with deionized water to remove unassimilated ${ }^{15} \mathrm{~N}$. The labeled Microcystis was then dried in the oven at $60{ }^{\circ} \mathrm{C}$ for $72 \mathrm{~h}$, and the detritus mass was ground into fine powder using a mortar and pestle.

Twenty-one high-density polyethylene (HDPE) mesocosms ( 130 L) were used. Each mesocosm was filled with $15 \mathrm{~cm}$ sediment and $90 \mathrm{~L}$ lake water that was pre-filtered using a plankton net $(64 \mu \mathrm{m})$. All mesocosms were floated in an artificial pond $(6 \times 5 \times 2 \mathrm{~m})$ located on the shore of Meiliang Bay. Similar-sized individuals of the snails Bellamya aeruginosa and Radix swinhoei, and the bivalves Corbicula fluminea, Anodonta woodiana and Unio douglasiae collected from Lake Taihu were added after 4 days according to the natural abundance of Lake Taihu (Cai et al., 2009). Zooplankton and meiofauna were naturally hatched from the added sediment in the mesocosms. The experiment was initiated by adding $7 \mathrm{~g}$ Microcystis detritus (labeled and powdered) to the water column of each mesocosm, except for the controls. The simulated concentration of chlorophyll-a was similar to the natural concentration of the lake described in a former study (Chen et al., 2003b) but much lower than the concentration reported by Qin et al. (2010) during the cyanobacteria blooming phase in Lake Taihu.

Particulate organic matter (POM including zooplankton), benthic macroinvertebrates, periphyton and surface sediments $(0-2 \mathrm{~cm})$ were sampled for analyses of nitrogen stable isotopes on days $0,3,5,9,14,20$ and 28 . Three random selected mesocosms were sampled in each sampling event, and the day 0 isotope values were used as controls. POM samples were prepared by filtering $2 \mathrm{~L}$ of water from the mesocosms over pre-weighed and pre-combusted GF/C filters. The surface sediments $(0-2 \mathrm{~cm})$ were sampled for isotopic analysis. All benthic snails and bivalves were picked directly after emptying of the mesocosms. About $5 \mathrm{~g}$ abdominal muscle tissue was sampled. Limnodrilus spp. was collected by washing the sediment left in the tank through a metal sieve of $150 \mu \mathrm{m}$. All worms were removed and transferred to 

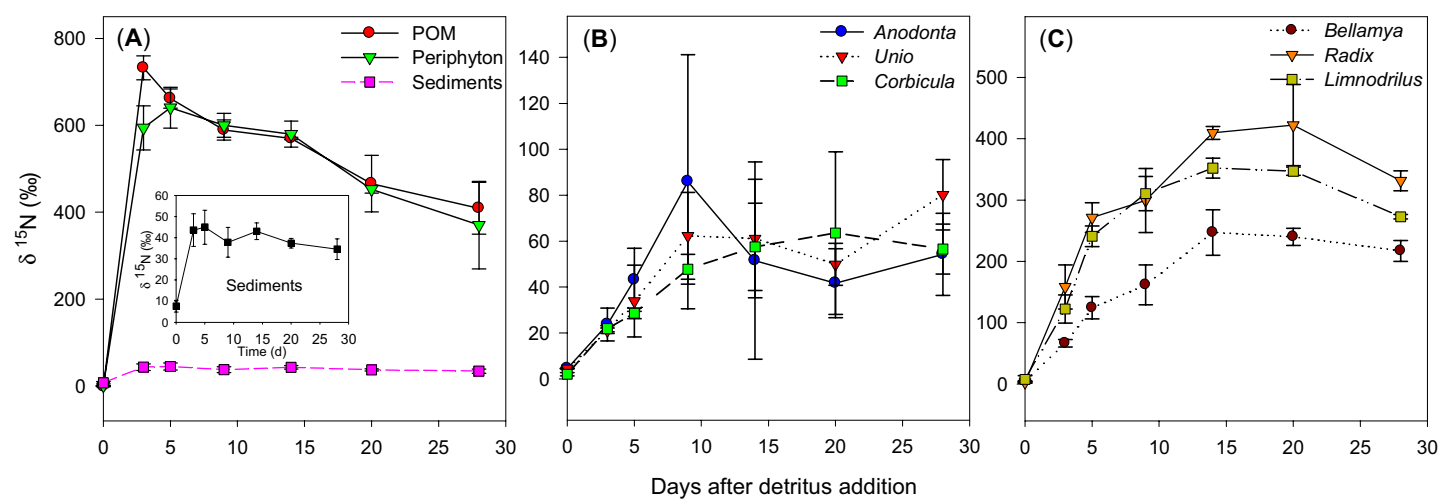

\section{Figure 1}

Variations in $\delta^{15} \mathrm{~N}$ signatures of pelagic and benthic organisms with time after addition of ${ }^{15} \mathrm{~N}$-labeled Microcystis detritus to the water column of the mesocosms. Error bars represent the standard deviation (SD) for three replicate tanks/mesocosms. Note: (A) periphyton (sampled from the inside wall of the mesocosm, POM (particulate organic matter) and sediments (surface $2 \mathrm{~cm}$ ); (B) bivalves (A. woodiana, $U$. douglasiae and C. fluminea), and (C) snails ( $R$. swinhoei and B. aeruginosa) and Limnodrilus spp.

filtered lake water for $24 \mathrm{~h}$ to empty their guts. Periphyton was sampled by brushing the whole wall of the tank into deionized water after emptying the water and sediments in the mesocosm carefully, a subsample of which was then filtered through pre-combusted and pre-weighed GF/C filters. All the samples were dried at $60^{\circ} \mathrm{C}$.

All samples were analyzed to determine ${ }^{15} \mathrm{~N} /{ }^{14} \mathrm{~N}$ ratios, using a SerCon $20-20$ isotope ratio mass spectrometer at the Department of Ecology and Institute of Hydrobiology, Jinan University, Guangzhou, China. Isotope abundance was expressed using the conventional delta notation against the conventional international standards (atmospheric nitrogen for $\delta^{15} \mathrm{~N}$ ): excess $\mu \mathrm{mol}$ of ${ }^{15} \mathrm{~N}$ per gram of dry sample, calculated according to Veuger et al. (2007).

Excess ${ }^{15} \mathrm{~N}\left(\mu \mathrm{mol} \cdot \mathrm{g}^{-1}\right)=\left[\left(\right.\right.$ at $\%{ }^{15} \mathrm{~N}_{\text {sample }}-$ at $\left.\% \mathrm{~N}_{\text {control }}\right) \times \mu \mathrm{mol}$ of $\mathrm{N}$ in tested sample $] /$ gram of dry tested sample

At $\%{ }^{15} \mathrm{~N}_{\text {sample }}=\left[100 \times R_{\text {air }} \times\left(\delta^{15} \mathrm{~N}_{\text {sample }} / 1000+1\right)\right] /\left[1+R_{\text {air }} \times\left(\delta^{15} \mathrm{~N}_{\text {sample }} / 1000+1\right)\right]$

retained ${ }^{15} \mathrm{~N}=$ excess ${ }^{15} \mathrm{~N} \times M_{\text {sample }}$

$\delta^{15} \mathrm{~N}(\%$ o $)=\left(R_{\text {sample }} / R_{\text {air }}-1\right) \times 1000$

where $R={ }^{15} \mathrm{~N} /{ }^{14} \mathrm{~N}$ and $M_{\text {sample }}=$ the total biomass (total dry weight) of the sample. The precision of repeated measurements was ca. $\pm 0.3 \%$.

All statistical analyses were performed using the statistical package SPSS version 16.0. Timecourse data were compared using Analysis of Variance for repeated measurements (rANOVA), and Tukey's post-hoc tests were performed to determine where the differences lay. The ultimate excess ${ }^{15} \mathrm{~N}$ values among benthic invertebrates were also compared using one-way ANOVA followed by Tukey's post-hoc test. Data were appropriately transformed where necessary to meet rANOVA requirements.

Immediately after addition of labeled Microcystis detritus, the mean $\delta^{15} \mathrm{~N}$ values of POM increased as expected, but also periphyton reached similar levels, likely reflecting attachment of the detritus to the walls. Thereafter, $\delta^{15} \mathrm{~N}$ decreased over time $(P<0.001)$, with a similar rate for the two variables (Figure $1 \mathrm{~A}$ ).

No significant differences in the $\delta^{15} \mathrm{~N}$ occurred among the bivalves $(P>0.05)$ (Figure 1B). $\delta^{15} \mathrm{~N}$ of $R$. swinhoei reached much higher levels $(P<0.05)$ than those of $B$. aeruginosa (Figure $1 \mathrm{C}$ ), while no significant differences in $\delta^{15} \mathrm{~N}$ content appeared between $R$. swinhoei and Limnodrilus $(P>0.05)$ (Figure $1 \mathrm{C})$. Although other phytoplankton may potentially be labeled by ${ }^{15} \mathrm{~N}$ release during decomposition of Microcystis detritus, enrichment of ${ }^{15} \mathrm{~N}$ in aquatic animals can most likely be ascribed to uptake of Microcystis detritus in such short incubation experiments as ours. 


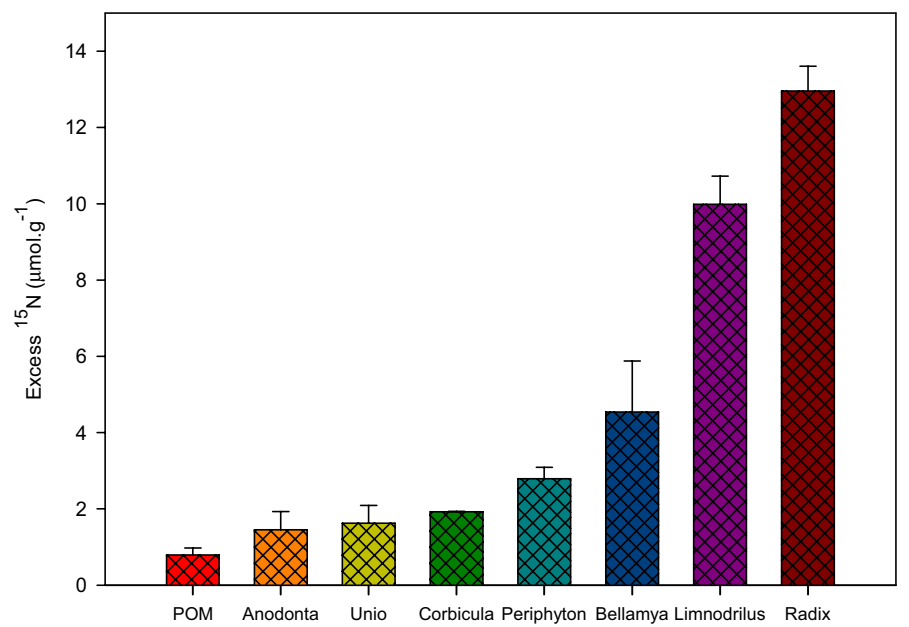

\section{Figure 2}

Comparison of excess ${ }^{15} \mathrm{~N}$ among organisms at the end of the experiment. Error bars represent the standard deviation (SD) for three replicate mesocosms.

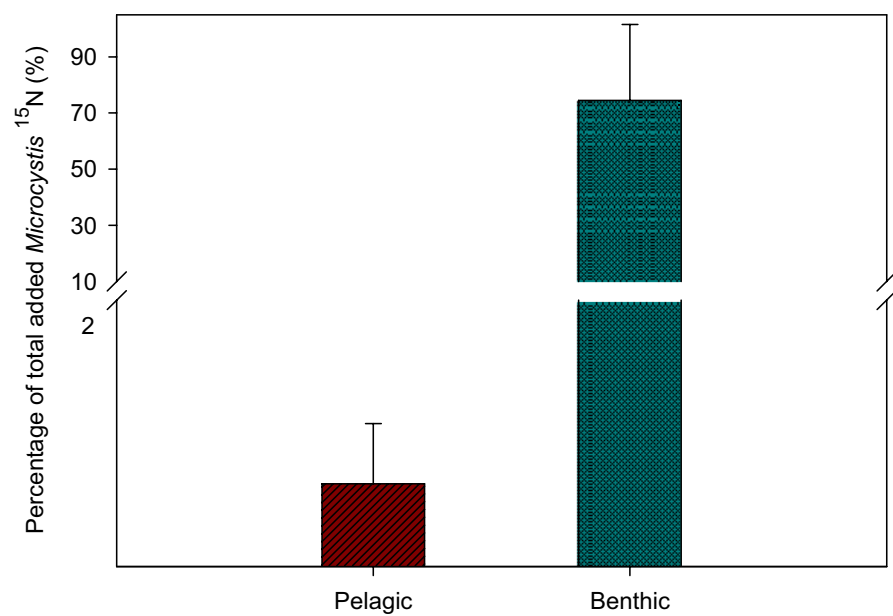

\section{Figure 3}

Percentage of total amount of added ${ }^{15} \mathrm{~N}$ (derived from Microcystis detritus) retained in the pelagic (POM, including phytoplankton and zooplankton) and benthic food webs (including periphyton of the inner mesocosm wall, benthic animals and surface sediment) at the end of the experiment. Error bars represent the standard deviation (SD) for three replicate mesocosms.

We found Limnodrilus spp. mostly on the sediment surface where they fed on organic materials, similarly to $B$. aeruginosa, while $R$. swinhoei generally fed on the inner wall of the mesocosms where periphyton was abundant. This is in accordance with the findings of $\mathrm{Li}$ et al. (2008), revealing that $R$. swinhoei prefers periphyton, and with those of Zheng et al. (2008), who showed that $B$. aeruginosa feed both on sediment organic matter and periphyton. An earlier study demonstrated phytoplankton to constitute an important nutrition source for salt marsh snails (Kurata et al., 2001), and Molina et al. (2011) found that the snail Biomphalaria depended strongly on bottom sediments as a nutrient source.

At the end of the experiment, the amounts of excess ${ }^{15} \mathrm{~N}$ in R. swinhoei and Limnodrilus spp. were significantly higher than in other organisms $(P<0.01)$, while no significant differences were found between these two species $(P>0.05)$ (Figure 2). Also, the excess ${ }^{15} \mathrm{~N}$ of the three bivalve species did not differ significantly by the end of the experiment $(P>0.05)$. Finally, approximately $70 \%$ of the added ${ }^{15} \mathrm{~N}$ was retained in the benthic food web, while less than $2 \%$ occurred in the pelagic food web (POM including zooplankton) (Figure 3). This indicates that the Microcystis detritus was more important for the benthic food web, or that the benthic 
consumers retained more cyanobacterial detritus than the pelagic organisms. Among the benthic invertebrates, Limnodrilus showed a high ability to incorporate nitrogen from the Microcystis detritus, which may explain the dominance of Tubificidae in some shallow eutrophic lakes with cyanobacterial blooms (Cai et al., 2012a; Cai et al., 2012b), although high fish predation in such lakes has a similar effect. In such lakes, cyanobacterial blooms will produce a large amount of detritus, providing a sufficient nutrition source to sustain the development of the Tubificidae community and shifting the benthic community structure dominated by oligochaetes. Furthermore, nitrogen from the Microcystis detritus can support growth of both submerged macrophytes (Zhang et al., 2010) and emergent plants (Li et al., 2010).

No wind- or animal-induced resuspension of surface sediments occurred in the mesocosm labeling experiment. Wind-induced sediment resuspension is a common phenomenon in natural shallow lakes (Bachmann et al., 2000). In Lake Taihu, nutrient-rich detritus in the surface sediments has been shown to be resuspended in the pelagic water by wind (Qin et al., 2006); thus, more cyanobacterial detritus in the surface sediment may be incorporated by the pelagic animals than recorded in this experiment.

In conclusion, our study found that nitrogen from Microcystis detritus was incorporated and retained by the invertebrates of Lake Taihu. Thus, in eutrophic lakes with cyanobacterial blooms, such as Lake Taihu, bloom detritus may serve as an important nutrient source in both the pelagic and benthic food webs; the nitrogen from cyanobacteria will be further transferred to higher trophic level consumers through trophic cascade relationships.

\section{ACKNOWLEDGEMENTS}

We thank Ke Li, Deyong Zhou, Xubo Liu, Sipeng Yao, Yachan Ji, Dongmei Cheng, Xu Wang and Zhijun Lv for field and laboratory support, and Anne Mette Poulsen for language assistance. Thanks also go to the two anonymous reviewers for their very constructive and helpful comments. This study was supported by the National Science Foundation of China (31370477; 41073057; 31170441), Jiangsu Planned Projects for Postdoctoral Research Funds (1301159C) and the Key Program of Nanjing Institute of Geography and Limnology, Chinese Academy of Sciences (NIGLAS2012135002).

\section{REFERENCES}

Bachmann R.W., Hoyer M.V. and Canfield Jr D.E., 2000. The potential for wave disturbance in shallow Florida lakes. Lake Reserv. Manage., 16, 281-291.

Cai Y., Gong Z. and Qin B., 2009. Standing crop and spatial distributional pattern of mollusca in Lake Taihu, 2006-2007. J. Lake Sci., 21, 713-719 (In Chinese with English abstract).

Cai Y., Gong Z. and Qin B., 2012a. Benthic macroinvertebrate community structure in Lake Taihu, China: Effects of trophic status, wind-induced disturbance and habitat complexity. J. Great Lakes Res., 38, 39-48.

Cai Y., Gong Z. and Xie P., 2012b. Community structure and spatiotemporal patterns of macrozoobenthos in Lake Chaohu (China). Aquat. Biol., 17, 35-46.

Chen Y., Qin B., Teubner K. and Dokulil M.T., 2003a. Long-term dynamics of phytoplankton assemblages: Microcystis-domination in Lake Taihu, a large shallow lake in China. J. Plankton Res., 25, 445-453.

Chen Y., Fan C., Teubner K. and Dokulil M., 2003b. Changes of nutrients and phytoplankton chlorophylla in a large shallow lake, Taihu, China: an 8-year investigation. Hydrobiologia, 506-509, 273-279.

Duan H., Ma R., Xu X., Kong F., Zhang S., Kong W., Hao J. and Shang L., 2009. Two-decade reconstruction of algal blooms in China's Lake Taihu. Environ. Sci. Technol., 43, 3522-3528.

Kurata K., Minami H. and Kikuchi E., 2001. Stable isotope analysis of food sources for salt marsh snails. Mar. Ecol-Prog. Ser., 223, 167-177.

Lampert W., 1987. Laboratory studies on zooplankton-cyanobacteria interactions. New Zeal. J. Mar. Fresh., 21, 483-490. 
Li K., Liu Z., Li C., Li Y.and Wen M., 2008. Food sources of snail Radix swinhoei in Lake Taihu. J. Lake Sci., 20, 339-343 (in Chinese with English abstract).

Li K., Liu Z. and Gu B., 2010. The fate of cyanobacterial blooms in vegetated and unvegetated sediments of a shallow eutrophic lake: A stable isotope tracer study. Water Res., 44, 1591-1597.

Molina C.I., Gibon F-M., Oberdorff T., Dominguez E., Pinto J., Marín R. and Roulet M., 2011. Macroinvertebrate food web structure in a floodplain lake of the Bolivian Amazon. Hydrobiologia, 663, 135-153.

Paerl H.W., 1988. Nuisance phytoplankton blooms in coastal, estuarine, and inland waters. Limnol. Oceanogr., 33, 823-847.

Qin B., Zhu G., Zhang L., Luo L., Gao G. and Gu B., 2006. Eatimation of internal nutrient release in large shallow Lake Taihu, China. Sci. China Ser. D, 49, 38-50.

Qin B., Zhu G., Gao G., Zhang Y., Li W., Paerl H.W. and Carmichael W.W., 2010. A drinking water crisis in Lake Taihu, China: linkage to climatic variability and lake management. Environ. Manage., 45, 105-112.

Veuger B., Eyre B.D., Maher D. and Middelburg J.J., 2007. Nitrogen incorporation and retention by bacteria, algae, and fauna in a subtropical intertidal sediment: An situ ${ }^{15} \mathrm{~N}$-labeling study. Limnol. Oceanogr., 52, 1930-1942.

Watson S.B., McCauley E. and Downing J.A., 1997. Patterns in phytoplankton taxonomic composition across temperate lakes of differing nutrient status. Limnol. Oceanogr., 42, 487-495.

Yu J., Li Y., Liu X., Li K., Chen F., Gulati R. and Liu Z., 2013. The fate of cyanobacterial detritus in the food web of Lake Taihu: a mesocosm study using ${ }^{13} \mathrm{C}$ and ${ }^{15} \mathrm{~N}$ labeling. Hydrobiologia, 710, 39-46.

Zhang L., Li K., Liu Z. and Middelburg J.J., 2010. Sedimented cyanobacterial detritus as a source of nutrient for submerged macrophytes (Vallisneria spiralis and Elodea nuttallii): An isotope labeling experiment using ${ }^{15}$ N. Limnol. Oceanogr., 55, 1912-1917.

Zheng Y., Wen M., Li K. and Wang H., 2008. Effects of Bellamya sp. on the growth of Vallisneria atans in Lake Taihu. Res. Environ. Sci., 21, 94-98 (In Chinese with English abstract). 